\title{
(6) \\ Midwakh/dokha tobacco use in the Middle East: much to learn
} OPEN ACCESS

\author{
S Vupputuri, ${ }_{1}^{1}$ C Hajat, ${ }^{2}$ M Al-Houqani, ${ }^{2}$ O Osman, ${ }^{2}$ J Sreedharan, ${ }^{3}$ R Ali, ${ }^{2,4}$ \\ A E Crookes, ${ }^{5}$ S Zhou, ${ }^{6}$ S E Sherman, ${ }^{7,8} \mathrm{M}$ Weitzman, ${ }^{6}$ on behalf of the United Arab \\ Emirates Tobacco Control Research Collaborative
}

${ }^{1}$ Kaiser Permanente Georgia, The Center for Health Research, Atlanta, Georgia, USA

2United Arab Emirates University, College of Medicine and Health Sciences, Institute of Public Health, Al Ain, UAE ${ }^{3}$ Gulf Medical University, Research Division, Ajman, UAE ${ }^{4}$ Cancer Epidemiology Unit, University of Oxford, Oxford, UK

${ }^{5}$ Heriot-Watt University, School of Life Sciences, Dubai, UAE

${ }^{6}$ Department of Pediatrics and Environmental Medicine, New York University School of Medicine, New York,

New York, USA

${ }^{7}$ New York University/Abu Dhabi Public Health Research Center, Abu Dhabi, UAE ${ }^{8}$ Department of Population Health, Medicine and

Psychiatry, New York University School of Medicine, New York, New York, USA

\section{Correspondence to} Dr Suma Vupputuri, Kaiser Permanente Georgia, Center for Health Research /SE, 3495 Piedmont Rd, Building 10 Suite 101, Atlanta, GA 30305, USA; suma133@hotmail.com

Received 17 January 2014 Accepted 27 August 2014 Published Online First 23 October 2014

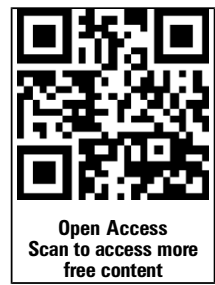

CrossMark

To cite: Vupputuri $S_{\text {, }}$

Hajat C, Al-Houqani M

et al. Tob Control

2016:25:236-241

\section{ABSTRACT}

Many alternative tobacco products (ATPs), such as hookahs, have grown in popularity and use beyond their locale of origin and are therefore becoming a significant global public health concern. This article provides an overview of an under-reported and understudied ATP, dokha, which is smoked in a midwakh pipe. It describes the state of tobacco control in the Arabian Gulf region where midwakh smoking appears to be most common, the history of midwakh and dokha use, and what is known about midwakh smoking from the published literature. On the basis of the stark lack of data on midwakh use, we suggest priority areas to focus future research. Preliminary data and observations from health providers and the public health sector suggest that midwakh smoking may pose challenges to the tobacco control efforts in the Arabian Gulf region. If it is emerging as a new ATP outside this region, there could be a significant impact on tobacco control strategies globally.

\section{INTRODUCTION}

Tobacco use is pervasive worldwide, and it has profound health consequences for smokers and those exposed prenatally or to secondhand or third-hand smoke (SHS and THS). ${ }^{1}$ Use of tobacco remains among the leading contributors to the global burden of disease, accounting for more than $10 \%$ of this burden in 2010 , and it is the leading preventable cause of non-infectious disease deaths worldwide. $^{1}{ }^{2}$ Changes in immigration patterns have resulted in significant changes in demographic characteristics of many parts of the world. This, in turn, has resulted in the introduction and diffusion of what had previously been region-specific forms of tobacco and tobacco delivery systems to many new parts of the world.

The increasing use of many such alternative tobacco products (ATPs) in areas that had not previously encountered them, coupled with the widespread implementation of public policies that have proven effective in limiting cigarette uptake and facilitating cessation of use, raises great concern that these ATPs may replace cigarettes as major forms of tobacco delivery systems. Evidence of this growing concern is provided by the WHO's Global Youth and Adult Tobacco Surveys, the Canadian and US National Youth Tobacco Surveys as well as the addition of many relevant questions to the US Behavioural Risk Surveillance System Survey. ${ }^{3-7}$ While substantially increasing attention is being paid to some ATPs, such as hookahs (also called water pipes, used to smoke shisha), bidis (thin, sometimes flavoured, cigarettes wrapped in the tendu or temburni leaf), kreteks (clove cigarettes), pan (betel quid with tobacco) and flavoured cigars and cigarillos, other ATPs of potential concern have to date largely been unrecognised and thus have not been studied, monitored or regulated.

This paper examines the use of midwakh/dokha, an ATP which is widely used in the United Arab Emirates (UAE) and the Arabian Gulf Region, where its use is prevalent and growing in popularity. Cursory indications, such as the proliferation of dokha websites and dokha sales at tobacco retailers internationally, suggest that midwakh/dokha use could potentially emerge outside the Gulf region. If true, it may follow a pattern similar to that of other ATPs such as hookahs, which have translated from cultural/traditional use in the Middle East to widespread global increases in use. Similar to hookahs, the marketing of midwakh/dokha is targeted at young people. ${ }^{8-12}$

\section{Tobacco use in the Arabian Gulf region}

In the Middle East and specifically the Arabian Gulf region, cigarette smoking has warranted and garnered serious public health concern. Among adults in this region, the point prevalence of active cigarette smoking was approximately $24 \%$ in men and $<1 \%$ in women, according to one of the largest surveys of adult tobacco use in the UAE. ${ }^{13}$ Further, it has been reported that $82 \%$ of students have tried their first cigarette before the age of 14. ${ }^{14}$ While exactly comparable metrics are not available globally, the following provides some context from other countries. Among regular cigarette smokers in the UK, approximately $65 \%$ started smoking before the age of 18 years $^{15}$ and in the USA, the mean age at which youth try their first cigarette is $15-16$ years. $^{16}$ The use of tobacco among those aged $13-15$ years in the UAE is increasing as shown by the Global Youth Tobacco Surveys, ${ }^{17} 18$ which indicates that current smoking of any tobacco product increased from $18 \%$ in 2002 to $20 \%$ in 2005 . While the use of cigarettes among those in this age group remained stable at $7-8 \%$, the use of ATPs such as cigars, pipes, little cigars, chewing tobacco, snuff and dip increased from $18 \%$ in 2002 to $29 \%$ in $2005 .{ }^{17}$ Hookah use was reported by $11 \%$ of participants in both years. ${ }^{17} 18$ These data suggest that the increase in tobacco smoking prevalence among young adults in this region may be due in part to the increased use of other ATPs. 
Tobacco control efforts in the Middle East and elsewhere continue to focus almost exclusively on curbing cigarette use (including smoking cessation training of health and education professionals, media campaigns, increased taxation and banning tobacco smoking in public places), despite the alarming new research indicating increased use of ATPs. Additionally, there is as yet little evidence on success rates for quit programme methods for ATPs, such as hookahs, which have spread in global use. The limited research literature suggests that many ATPs may be as harmful as or even more harmful than cigarettes; ${ }^{19-24}$ however, with respect to midwakh use, there is a critical lack of data on prevalence, attitudes, knowledge, toxicant exposure and health consequences.

\section{What is midwakh and dokha?}

Dokha (Arabic for 'dizzy') is the tobacco blend that is smoked in a pipe called a 'midwakh'. It is a combination of tobacco leaves with a variety of barks, herbs, spices, dried flowers or dried fruit, and is known for its high nicotine content, containing up to five times as much as a normal cigarette. ${ }^{25}{ }^{26}$ Dokha use originated in northern Iran in the 15 th century ${ }^{8}$ and widespread use among sailors along the Caspian Sea resulted in its introduction into the Middle East in the 1500s.

The midwakh is used to inhale the smoke of the burning dokha, and this pipe is structurally different from other Western smoking pipes (see figure 1). Since the bowl of the midwakh pipe is small, it normally holds only $\sim 0.5 \mathrm{mg}$ of dokha per use, thus requiring only 1-2 inhalations to fully burn the dokha before the pipe needs to be refilled. ${ }^{13}$ These two inhalations, however, may expose the smoker to nicotine and other tobacco constituents equal to or more than the exposure of cigarette inhalation. ${ }^{13}$ There is little information about comparative exposures between dokha and other tobacco products, or the exposure to and effects of SHS and THS to dokha.

Since dokha tobacco is smoked almost exclusively in a midwakh pipe, its use is often referred to interchangeably as dokha or midwakh use. In this paper, we will utilise the term 'midwakh use' or 'midwakh smoking' to represent the smoking of dokha tobacco in a midwakh pipe (and only refer to dokha when referring to the tobacco product itself).

Midwakh smoking is commonplace in parts of the Arab world and it appears to some that it may be growing in popularity (although no evidence as of yet is available to substantiate this observation). We also believe that it is possible that midwakh smoking may emerge in Western countries among 'youth sub-cultures' based on the acceleration of websites selling midwakh and dokha and anecdotal observations of sales of midwakh and dokha in specialty stores in Western countries. ${ }^{8-12}$ Midwakh smoking (and the use of dokha tobacco) is the second most common form of tobacco used (after cigarettes) among men in Abu Dhabi in the UAE. ${ }^{13}$ Aside from hookahs, very little

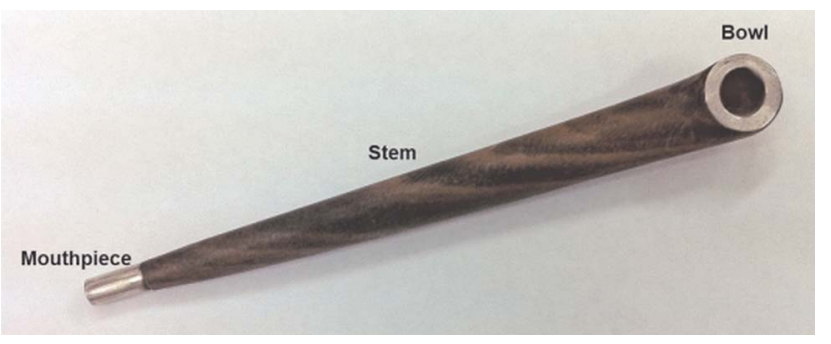

Figure 1 Photograph of midwakh pipe. is known about the use of other ATPs and alternative tobacco delivery systems emanating from the Middle East to other parts of the world. The diffusion of the use of these products among the overall population is largely unknown, although almost $20 \%$ of US adolescents report having used hookahs and more than $2 \%$ report having used bidis or kreteks before completing high school. ${ }^{7}$ In contrast, virtually nothing is known about the use of midwakh in Western countries. This problem is compounded by the absence of questions about it on any global or national tobacco survey outside the Arabian region. Despite this paucity of systematic public health information, numerous North American and European websites have emerged that market midwakh smoking, especially to youth, as the 'the future of tobacco. $^{8} 27$ These websites emphasise midwakh smoking as: having 'more feeling', time saving, less mess, odourless, economical, the newest trend and as a healthier option than cigarettes. The marketing message of midwakh use in the West is that of a trendy pastime and it has begun to appear on various merchandise items (figure 2).

\section{The potential emergence of midwakh in the West?}

The effect of globalisation and population mobility on public health is not a new concept. ${ }^{28}$ With dramatic changes in the demographics of Europe and North America, we believe that it is possible that the emergence of ATPs, such as hookah use, in the West is due, at least in part, to the immigration patterns and changing population demographics. ${ }^{29} 30$ With the popularity of midwakh use in the Gulf region, it is also possible for its use to gain popularity among immigrant populations in the West and transfer to native populations. Further, many of the current websites that sell dokha and midwakh are based in the USA or the UK. ${ }^{27} 3132$ As suggested by these websites, there are many more shops and vendors in these Western countries that sell and market midwakh and dokha products. For example, on

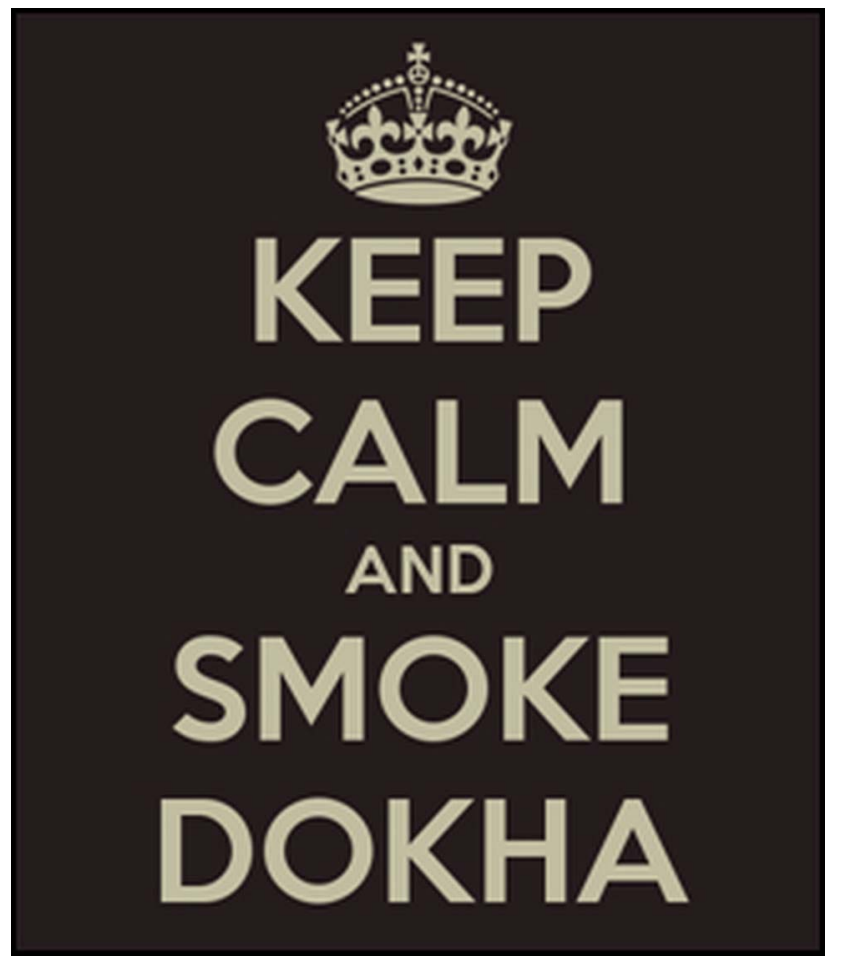

Figure 2 Marketing image found on posters, t-shirts, mugs and key chains. 
Medwakh.com, 238 retailers are listed across the USA that sell midwakh/dokha. ${ }^{32}$

There is a profound concern about the use of ATPs in the USA, and the US Food and Drug Administration (FDA) is now proposing new regulations including banning sales to those under 18 and requiring disclosure of ingredients. ${ }^{33}$

While we cannot comment definitively on the emergence of midwakh in the West at a population level, its cultural popularity in the Arabian Gulf region and in similar communities in the West is becoming apparent. American-based retailers of midwakh and dokha seem to have developed, at least in part, a clientele who have tried midwakh in the Arabian Gulf region and are interested in continuing to use midwakh while living in the USA. Several quotes from an online retailer/forum illustrate this point ${ }^{31}$ :

Wassim J-Fairfax, VA: Dokha.com provides a service unmatchable by others in the US and provides great customer service for all smoking needs. It is a great place to order from if you are like me who has moved from Dubai to the US...

Alex C-Edison, NJ: Amazing that you can get something soo good from afar so nearby. The delivery of the dokha is always within 2 days of ordering and not once have i received stale dokha...

Alp Cem-Sugarland, TX: Dokha.com is the easiest way to get Dokha in North America...I have bought over 20 bottles from them and 2 pipes, it's just like the Dokha sellers back in the middle east. In case you are like us, moved here from the middle east, don't fret, Mark (the owner of the store) has got you covered.

The demographics of Europe and North America are changing dramatically, with increasing numbers of immigrants from East and South Asia, Latin America and the Middle East. For example, over the past two decades, the immigrant population in the USA has increased steadily at a rate of $\sim 1$ million per year and there has been a dramatic shift in the national origin of immigrants. In the early to mid 1900s, the majority of immigrants to North America were of European origin, ${ }^{34}$ while in 2010, 39\% of immigrants to the USA were from Asia (including those emigrating from the Middle East), ${ }^{34}$ and in Canada 25\% of immigrants were from Africa or the Middle East. In Canada, the Middle Eastern population (West Asians and Arabs) constitutes the fastest growing immigrant group. Demographic trends of increasing global emigration mean that regional public health concerns of ATPs such as midwakh smoking may translate to a serious global public health issue.

\section{WHAT IS AND IS NOT KNOWN ABOUT MIDWAKH USE}

While a handful of published studies suggest that the use of midwakh is common in the Gulf region, ${ }^{13}{ }^{35-37}$ the lack of data is striking. We conducted an electronic literature search by using the MEDLINE database of the National Library of Medicine, HealthSTAR and Google Scholar, from database inception until the end of January 2013.. The search terms included: 'midwakh', 'medwakh', 'dokha' and 'Arab pipe'. Table 1 provides a summary of the four published studies on midwakh use that resulted from the search.

In the largest study published to date on midwakh use, Al-Houqani et $a l^{13}$ reported on a cross-sectional analysis of data concerning a nationally representative sample of 170430 adult UAE nationals. Participants self-reported tobacco smoking habits via a questionnaire and data were collected over a 2-year period. Midwakh use was the most common tobacco product used after cigarettes, accounting for $15 \%$ of all tobacco smokers, and the users were predominantly men. Among midwakh users, on average, age was 30 years, duration of use was 9.3 years and frequency of use was 12 times per day. The authors concluded that the use of midwakh, particularly given the young age of onset of use, is an important concern for public health activities and policy in Abu Dhabi. They also expressed concern about the spread of midwakh use to other countries.

In another smaller, cross-sectional study Jayakumary et al ${ }^{36}$ surveyed 104 students, aged 17-27 years, attending Gulf Medical University in Ajman, UAE. Thirty per cent of males and $5 \%$ of females reported dokha use. Among dokha smokers, $33 \%$ smoked more than 100 times in their lifetime and $17 \%$ reported having smoked 26-100 times in their lifetime; 16\% smoked more than 7-10 times per day during the past 30 days and $25 \%$ smoked on all days during the previous month. These findings are especially alarming as they are derived from a select group of individuals training to be physicians.

The third study was a small pre-post study with no controls conducted to assess the acute effects of smoking dokha. ${ }^{37}$ Study participants were 97 volunteer, male university students (Emiratis, other Arabs and other nationalities) who were consecutively sampled. The results were similar to those found with other forms of smoking with mean increases in systolic blood pressures $(12 \pm 1 \mathrm{~mm} \mathrm{Hg})$, heart rate $(20 \pm 2 \mathrm{bpm})$ and respiratory rate $(4 \pm 1$ breaths/min).

In a recently published study, the prevalence of midwakh use was assessed among adult Abu Dhabi marriage license applicants (using the Abu Dhabi Premarital Screening programme). ${ }^{35}$ All couples who apply for a marriage license are required to undergo several medical tests and complete a survey on behavioural risk factors. The data showed that, among men overall, the prevalence of midwakh smoking was $12 \%$. By nationality, UAE nationals had the highest prevalence of midwakh use (16\%), followed by Arab expatriates (4\%) and other expatriates (3\%).

After reviewing the literature, it is clear that very little research has been carried out to explore the extent of midwakh use in population-based samples or the potential harms that may result from midwakh smoking. Only two studies were large enough to provide adequate estimation of the prevalence of midwakh use (ranging from $12-15 \%$ in men). While the published scientific literature is meagre, anecdotally, according to practising healthcare providers, public health workers and the

Table 1 Summary of studies on midwakh use

\begin{tabular}{lllll}
\hline Author & Design & Sample size/population & Time frame of data collection & Outcome measure \\
\hline Al-Houqani et $a l^{13}$ & Cross-sectional & $\mathrm{N}=170430$ virtually complete capture of adult UAE nationals & 2.2 years & Prevalence of midwakh use \\
Shaikh $e t a l^{37}$ & Pre-post & $\mathrm{N}=97$ convenience sample of male university students in the UAE & 1 day & Acute blood pressure \\
Jayakumary et al ${ }^{36}$ & Cross-sectional & $\mathrm{N}=104$ university students in the UAE & 1 year & Prevalence of dokha use \\
Aden $e t a l^{35}$ & Cross-sectional & $\mathrm{N}=9337$ adult applicants for marriage license in the UAE & 9 months & Prevalence of midwakh use \\
\hline
\end{tabular}


media, midwakh smoking is commonplace in the Arab Gulf region. Continued and expanded research to better understand the problem of midwakh smoking is needed.

\section{FUTURE RESEARCH PRIORITIES FOR MIDWAKH USE}

Given the high reported prevalence of midwakh use in the UAE and the almost complete lack of scientific and public data on midwakh use, there is a pressing need for more research about this ATP. The main purpose of this section is to suggest how we can best expand and enhance the existing body information on midwakh use. The key will be to start with the regions where studies can confirm that midwakh use is a convincing public health issue and using that as a basis to inform strategies to examine midwakh use outside of the Middle East.

\section{Qualitative data from midwakh users}

Personal accounts and marketing suggest that users believe that midwakh is a safer, more convenient alternative to cigarettes. However, the specific motivations of midwakh users are not known. Focus groups aimed at systematically assessing knowledge, beliefs, attitudes, risk perception, communication patterns, preferences, influences and modes of procurement can provide insight into the behaviour of these users. It will also be important to explore cultural dimensions of midwakh use, such as tradition, family and social norms. Results from these qualitative data will not only provide key insight on midwakh users, but will also inform subsequent studies and encourage more focused research questions for population-level observational studies of midwakh behaviours and related health outcomes. Understanding the factors that may be contributing to the rise in midwakh use in the UAE and Arabian Gulf region is critical to developing appropriately tailored prevention, cessation and policy interventions. Additionally, understanding the differences, if any, between midwakh use in the Middle East compared with the West may also be key in curbing the spread of its use.

Other qualitative research that would provide important information regarding midwakh use is a systematic search of websites representing retailers to report on the content of information posted, customer comments and blogs, types of dokha for sale, and the price of dokha and midwakh. In a related study on hookah tobacco smoking establishments advertised on the internet, ${ }^{38}$ it was found that websites were spreading misinformation related to hookah use. If this is similarly true regarding midwakh use, this misinformation needs to be countered with targeted health education and policy measures. These types of studies will also be important to document how individuals procure dokha tobacco.

\section{Inclusion of midwakh use in population-based surveys to better understand the determinants, deterrents and distribution of its use.}

There are many ongoing regional and global population-based studies on tobacco smoking habits in the Middle East, including the Weqaya Cardiovascular Screening Programme (Abu Dhabi, UAE; 2008-2013), ${ }^{39}$ the Global Youth Tobacco Survey (UAE, Bahrain, Oman, Lebanon, Kuwait, Iran, Egypt; 2002 and 2005), the Global Adult Tobacco Survey (Egypt; 2007) and the Global Health Professionals Survey (Egypt; 2005). Of these surveys, however, only the Weqaya Cardiovascular Screening Programme has specifically reported on the use of midwakh. The Weqaya questionnaire (as reported in the paper by Al-Houqani et $a l^{13}$ ) used four key questions to assess midwakh prevalence: (1) Do you currently smoke or have you ever smoked midwakh/dokha? (2) How much do or did you smoke midwakh/dokha per day?
(3) How old were you when you started using midwakh/dokha? (4) For how long have you or did you smoke midwakh/dokha? These questions provide information on the prevalence of midwakh use and serve as important baseline estimates. Since Weqaya is an ongoing screening programme, future analyses of trends in midwakh use over time will be possible. Further, these questions will provide a foundation on which to build more nuanced and in-depth surveys. The current Global Youth Tobacco Survey being conducted in Abu Dhabi, UAE will also incorporate new questions about midwakh use; however, these data are not yet published. Improving the availability of data on midwakh use, exposure and related health outcomes through surveillance and monitoring will be a key activity to assess its burden and identify population and time trends. It will be important to do this using standardised evidence-based protocols and instruments; using representative samples; conducting surveys at regular intervals; and establishing the capacity to analyse and publish results. The inclusion of Gulf region countries in the WHO global tobacco-free initiative will also be a crucial task. In Western countries, such as the USA, Canada and Europe, the inclusion of specific questions on midwakh use in population-based surveys will also be key, focusing in particular on geographic areas with high concentrations of Middle Eastern immigrants.

Since decreases in the prevalence of tobacco use are often preceded by a decrease in use among health professionals and other opinion leaders and early adopters of health-related behaviours, particular focus is needed to study the prevalence of midwakh use among health professionals, public health officials and other professionals. Healthcare professionals are not only responsible for primary and specialty healthcare for tobacco related conditions, but they are also responsible for tobacco cessation counselling and treatment, and education regarding exposure to SHS and THS, in addition to serving as community role models.

\section{The use of social media databanks to assess trends in midwakh use}

Social media, such as Twitter and Facebook, allow users to share thoughts, opinions and random details of their lives. While many messages are of little value to health research, the aggregation of millions of messages can generate important knowledge, patterns and trends on a range of public health issues. For example, recent work was able to correlate trends in Twitter messages that mention influenza with influenza rates as documented by the Centers for Disease Control in the USA. ${ }^{40}{ }^{41}$ Social media may also provide important information on health behaviours. Owing to the lack of available data on midwakh/ dokha use, utilising information from social media data banks could provide new and important information on patterns of use, geographic distribution, temporal trends and user perceptions. Such a study could be conducted at minimal cost, and with relative immediacy.

\section{Assessment of the effects of dokha use on cardiorespiratory and other systems}

Tobacco use has numerous, serious pathophysiological effects which may be immediate and short-lived or have more longterm consequences. The literature largely describes the effects of tobacco through cigarette use. The effects of other forms of tobacco use may differ and the body of this research literature is currently sparse. More studies on the effect of dokha on the cardiorespiratory and other systems, especially compared with cigarette tobacco, are needed. Preliminary research ${ }^{36}$ (described 
above) has demonstrated that dokha had similar acute effects on blood pressure and respiratory rate as other forms of smoking; however, larger studies are needed that look at additional outcomes such as expired air carbon monoxide, blood carboxyhaemoglobin, cotinine and inflammatory marker levels, as well as puff topography (a measure of acute smoking behaviour using a device to assess puff volume, duration, number, peak flow rate and interpuff interval). Anecdotal reports by smoking cessation physicians and users refer to immediate dizziness after smoking dokha, implying a rapid physiological effect. Studies suggest that other ATPs such as hookahs may have more detrimental health effects than cigarettes. ${ }^{19-24}$ Currently, very little is known about nicotine addiction among any ATP users.

\section{Data on the economic aspects of midwakh use}

Understanding the economic aspect of a business or industry is an important early step in developing beneficial public policies. Enormous profits have been made by the tobacco industry sacrificing public health and well-being, and leaving behind a serious economic burden and personal suffering. ${ }^{1}$ While economic research has demonstrated the effectiveness of higher tobacco product taxes in reducing tobacco use, these methods are not effective for all countries. For example, the Gulf Council Countries apply a $100 \%$ tariff on importers' declared cost, insurance and freight value, yet the average price of cigarettes in the Gulf region remains lower than the average global price. ${ }^{42}$ With locally produced and inexpensive tobacco options such as midwakh readily available in the UAE, efforts to curb tobacco use become even more challenging. Additionally, when considering the potentially changing patterns in tobacco use, and the rise of ATPs including midwakh use globally, it will be important to monitor their sales by region and by nation, distribution patterns and profit margins. This can be done, for example, by auditing a sample of retailers of dokha and midwakh, examining retailer characteristics and annual sales and comparing characteristics by region. By investigating the economic incentives and distributions of midwakh, researchers and policymakers alike will be able to track its pattern of consumption, motivations behind the sell and successful business strategies. Consequently, policymakers will be able to plan more focused and effective interventions.

\section{CONCLUSIONS}

In the past decade, ATP use has been steadily increasing around the world. Far less is known about these tobacco products than about cigarettes, and the product for which the most information is known, namely hookahs, is still rudimentary. With a striking lack of data on almost all aspects of midwakh use, and the possibility of an increasing prevalence of a potentially more

Key messages

- The current manuscript consolidates and summarises the sparse body of literature on midwakh smoking in the Middle East.

- Authors postulate, through insights and opinions, on the threat of midwakh use to tobacco cessation efforts, as well as its potential emergence globally.

- This manuscript also provides key recommendations with which to guide and prioritise future, needed, research efforts on the public health effects of midwakh smoking. harmful form of tobacco, it is clear that immediate studies are needed. Investment in research and monitoring to understand midwakh use in the Middle East is necessary to evaluate its potential public health threat. Midwakh use may have implications for public health programmes, policy initiatives and tobacco control worldwide.

Contributors All authors contributed to the conception and design of the manuscript as well as revising it critically for important intellectual content. SV, CH, SES and MW drafted the manuscript.

\section{Competing interests None.}

Provenance and peer review Not commissioned; externally peer reviewed.

Open Access This is an Open Access article distributed in accordance with the Creative Commons Attribution Non Commercial (CC BY-NC 3.0) license, which permits others to distribute, remix, adapt, build upon this work non-commercially, and license their derivative works on different terms, provided the original work is properly cited and the use is non-commercial. See: http://creativecommons.org/ licenses/by-nc/3.0/

\section{REFERENCES}

1 Eriksen M, Mackay J, Ross H. The tobacco atlas. 4th edn. Atlanta, GA: American Cancer Society, 2012. New York, NY: World Lung Foundation.

2 World Health Organization (WHO). Report on the global tobacco epidemic: warning about the dangers of tobacco. Geneva: WHO, 2011.

3 Centers for Disease Control and Prevention (CDC). Current tobacco use among middle and high school students_-United States, 2011. MMWR Morb Mortal Wkly Rep 2012;61:581-5.

4 Eaton DK, Kann L, Kinchen S, et al. Youth risk behavior surveillance. MMWR Surveill Summ 2012;61:1-162.

5 Leatherdale ST, Rios P, Elton-Marshall T, et al. Cigar, cigarillo, and little cigar use among Canadian youth: are we underestimating the magnitude of this problem? J Prim Prev 2011;32:161-70.

6 Morton J, Song Y, Fouad $\mathrm{H}$, et al. Cross-country comparison of waterpipe use: nationally representative data from 13 low and middle-income countries from The Global Adult Tobacco Survey (GATS). Tob Control 2014;23:419-27.

7 Warren CW, Riley L, Asma S, et al. Tobacco use by youth: a surveillance report from the Global Youth Tobacco Survey Project. Bull World Health Organ 2000;78:868-76.

8 Dokha. http://www.facebook.com/pages/Dokha/10312749639377 (accessed 29 Dec 2013).

9 Enjoy Dokha. http://www.facebook.com/EnjoyDokha (accessed 29 Dec 2013).

10 Iconic Dokha. http://www.facebook.com/iconicdokha (accessed 29 Dec 2013)

11 Medwakh/Dokha. http://www.facebook.com/medwakh.dokha (accessed 29 Dec 2013).

12 Midwakh. http://www.facebook.com/midwakh (accessed 29 Dec 2013).

13 Al-Houqani M, Ali R, Hajat C. Tobacco smoking using midwakh is an emerging health problem-evidence from a large cross-sectional survey in the United Arab Emirates. PLOS ONE 2012;7:e39189.

14 Al Suwaidi J, Zubaid M, El-Menyar AA, et al. Prevalence and outcome of cigarette and waterpipe smoking among patients with acute coronary syndrome in six Middle-Eastern countries. Eur J Prev Cardiol 2012;19:118-25.

15 Robinson S, Bugler C. Smoking and drinking among adults, 2008. Newport, UK: The Office of National Statistics, 2010.

16 McClave AK, Whitney N, Thorne SL, et al. Adult Tobacco Survey. MMWR Surveill Summ 2010;59:1-75.

17 Haidar H. United Arab Emirates (Ages 13-15) Global Youth Tobacco Survey (GYTS), Fact Sheet 2005. CDC. http://apps.nccd.cdc.gov/GTSSData/Ancillary/DataReports. aspx?CAID=1 (accessed 29 Dec 2013).

18 Abi Saab B. United Arab Emirates (Ages 13-15) Global Youth Tobacco Survey (GYTS), Fact Sheet 2002. CDC. http://nccd.cdc.gov/GTSSData/Ancillary/DataReports. aspx?CAID=1 (accessed 29 Dec 2013).

19 Rahman M, Fukui T. Bidi smoking and health. Public Health 2000;114:123-7.

20 Rahman M, Sakamoto J, Fukui T. Bidi smoking and oral cancer: a meta-analysis. Int J Cancer 2003;106:600-4.

21 Polzin GM, Stanfill SB, Brown CR, et al. Determination of eugenol, anethole, and coumarin in the mainstream cigarette smoke of Indonesian clove cigarettes. Food Chem Toxicol 2007;45:1948-53.

22 Mohammad Y, Kakah M, Mohammad Y. Chronic respiratory effect of narguileh smoking compared with cigarette smoking in women from the East Mediterranean region. Int J Chron Obstruct Pulmon Dis 2008;3:405-14.

23 Luo J, Ye W, Zendehdel K, et al. Oral use of Swedish moist snuff (Snus) and risk for cancer of the mouth, lung, and pancreas in male construction workers: a retrospective cohort study. Lancet 2007;369:2015-20.

24 Blank MD, Nasim A, Hart A Jr, et al. Acute effects of cigarillo smoking. Nicotine Tob Res 2011;13:874-9. 
25 Arabic medwakh pipes and dokha tobacco. http://www.sarudama.com/ miscellaneous/arabic_midwakh_pipes_and_dokha.shtml (accessed 29 Dec 2013).

26 Moussly R. Dubai's teenage take to 'Dokha'. 2012. http://gulfnews.com/news/gulf/ uae/education/dubai-s-teenagers-take-to-dokha-1.1039067 (accessed 29 Dec 2013).

27 Dokha the future of tobacco. http://www.dokhausa.com (accessed 29 Dec 2013).

28 Collin J, Lee K. Globalisation and transborder health risk in the UK: case studies in tobacco control and population mobility. London: The Nuffield Trust, 2003. http:/l www.socialpolicy.ed.ac.uk/_data/assets/pdf_file/0003/58737/Globalisation_and_ Transborder_health_risk_in_the_UK.pdf

29 American Lung Association. Hookah smoking: a growing threat to public health issue brief. Smoke free Communities Project. http://www.lung.org/stop-smoking/ tobacco-control-advocacy/reports-resources/cessation-economic-benefits/reports/ hookah-policy-brief.pdf (accessed 10 Jul 2014).

30 Johnston LD, O'Malley PM, Miech RA, et al. Monitoring the future, national survey results on drug use 1975-2013: overview, key findings on adolescent drug use. Ann Arbour: Institute for Social Research, The University of Michigan, 2014. http://www.monitoringthefuture.org/pubs/monographs/mtfoverview2013.pdf

31 Dokha.Com: We Adore Our Customers! http://www.dokha.com/customerfeedback (accessed 10 Jul 2014).

32 Medwakh.com. http://www.medwakh.com/ (accessed 10 Jul 2014).

33 FDA Proposes To Extend Its Tobacco Authority To Additional Tobacco Products, Including E-Cigarettes. FDA News Release. April, 2014. 2014. http://www.fda.gov/ newsevents/newsroom/pressannouncements/ucm394667.htm (accessed 10 Jul 2014).
342010 Yearbook of Immigration Statistics. 2011. Washington D.C., U.S. Department of Homeland Security, Office of Immigration Statistics.

35 Aden B, Karrar S, Shafey O, et al. Cigarette, water-pipe, and medwakh smoking prevalence among applicants to Abu Dhabi's Pre-Marital Screening Program, 2011. Int J Prev Med 2013;4:1290-5.

36 Jayakumary $\mathrm{M}$, Jayadevan $\mathrm{S}$, Ranade $\mathrm{AV}$, et al. Prevalence and pattern of dokha use among medical and allied health students in Ajman, United Arab Emirates. Asian Pac J Cancer Prev 2010;11:1547-9.

37 Shaikh RB, Abdul Haque NM, Abdul Hadi Khalil Al Mohsen $\mathrm{H}$, et al. Acute effects of dokha smoking on the cardiovascular and respiratory systems among UAE male university students. Asian Pac J Cancer Prev 2012;13:1819-22.

38 Primack BA, Rice KR, Shensa A, et al. U.S. Hookah tobacco smoking establishments advertised on the internet. Am J Prev Med 2012;42:150-6.

39 Hajat C, Harrison O, Al Siksek Z. Weqaya: a population-wide cardiovascular screening program in Abu Dhabi, United Arab Emirates. Am J Public Health 2012;102:909-14.

40 Achrekar H, Gandhe A, Lazarus R, et al. Predicting flu trends using Twitter data. Computer Communications Workshops (INFOCOM WKSHPS); 10-15 April 2011. Shanghai: Institute of Electrical and Electronics Engineers (IEEE), 2011:702-7.

41 Boman M, Cakici B, Guttmann C, et al. Syndromic surveillance in the United Arab Emirates. Innovations in Information Technology (IIT); 18-20 March 2012. Institute of Electrical and Electronics Engineers (IEEE), 2012.

42 World Health Organization (WHO). Technical manual on tobacco tax administration. Geneva: WHO, 2014. http://whqlibdoc.who.int/publications/2010/9789241563994_ eng.pdf?ua=1 